Journal of Clinical Investigation

Vol. 42, No. 12, 1963

\title{
STUDIES ON NORMAL AND LEUKEMIC LEUKOCYTES. VI. THYMIDYLATE SYNTHETASE AND DEOXYCYTIDYLATE DEAMINASE*
}

\author{
By ROBERT SILBER, $\dagger$ BEVERLY W. GABRIO, AND F. M. HUENNEKENS $\ddagger$ with the \\ TECHNICAL ASSISTANCE OF ALINE ALENTY \\ (From the Department of Biochemistry, University of Washington, and King County Central \\ Blood Bank, Seattle, Wash.)
}

(Submitted for publication July 2, 1962 ; accepted August 16, 1963)

Thymidylate, a key precursor of DNA, ${ }^{1}$ is synthesized by the tetrahydrofolate-dependent methylation of deoxyuridylate or by the phosphorylation of thymidine via thymidine kinase (3). The former reaction, catalyzed by thymidylate synthe- tase, has been the subject of several investigations (4-6) including that of Wahba and Friedkin $(7,8)$, who established the stoichiometry shown in Equation 1.

$$
N^{5}, N^{10} \text {-methylene tetrahydrofolate }+\mathrm{dUMP} \rightarrow \mathrm{TMP}+\text { dihydrofolate }
$$

The $\mathrm{C}_{1}$ unit is transferred from $N^{5}, N^{10}$-methylene tetrahydrofolate to $\mathrm{dUMP}$, and this reductive methylation step is coupled with the oxidation of tetrahydrofolate to dihydrofolate. Dihydrofolate is then recycled to tetrahydrofolate by the action of dihydrofolic reductase, and the addition of a $\mathrm{C}_{1}$ unit, possibly via serine hydroxymethylase, completes the "thymidylate cycle" as outlined in Equation 2 .

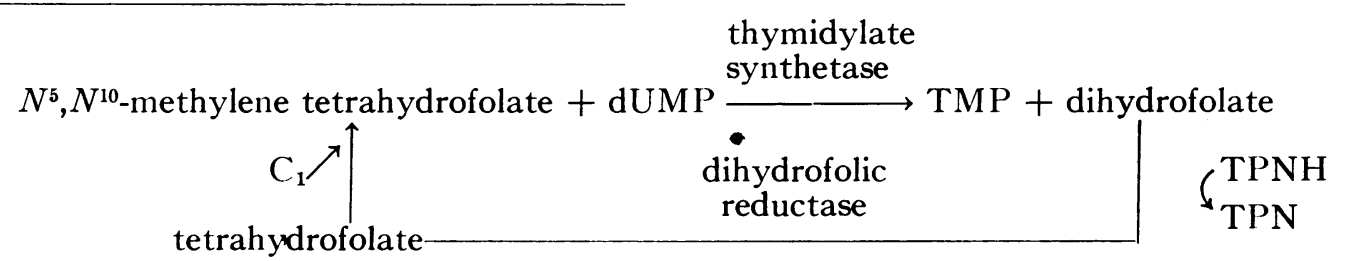

The present investigation is concerned with the characterization of thymidylate synthetase from human leukocytes and with the levels of this en-

* This investigation was supported by a grant (P-203) from the American Cancer Society. Preliminary reports of this work have appeared elsewhere $(1,2)$.

$\dagger$ Special fellow of the National Cancer Institute. Present address: Department of Medicine, New York University, New York, N. Y.

$\ddagger$ Present address : Division of Biochemistry, Scripps Clinic and Research Foundation, La Jolla, Calif.

1 Abbreviations: UMP, uridine-5'-phosphate; dUMP, deoxyuridine-5'-phosphate; CMP, CDP, CTP, cytidine mono-, di-, and triphosphate; dCMP, dCDP, dCTP, deoxycytidine mono-, di-, and triphosphate; TMP, TTP, thymidine mono- and triphosphate; DNA, deoxyribonucleic acid; RNA, ribonucleic acid; Tris, tris(hydroxymethyl)aminomethane; FUDR, fluorodeoxyuridine; FUDRP, fluorodeoxyuridine-5'-phosphate; DEAE, diethylaminoethyl; $\mathrm{C}_{t}, 1$-carbon unit; $\mathrm{AML}$ and $\mathrm{CML}$, acute and chronic myelocytic leukemia; ALL and CLL, acute and chronic lymphocytic leukemia. zyme in normal and leukemic leukocytes. Studies are also presented on an ancillary enzyme, deoxycytidylate deaminase, which is responsible for the conversion of dCMP to dUMP via Equation 3 .

$$
\text { deoxycytidylate }+\underset{\text { deoxyuridylate }}{\mathrm{H}_{2} \mathrm{O}} \rightarrow \mathrm{NH}_{3}
$$

\section{METHODS}

The following materials were used: $\mathrm{C}^{14}$-formaldehyde (10 $\mu \mathrm{c}$ per $\mu \mathrm{mole}) ;{ }^{2}$ DNA ; ${ }^{3}$ protamine sulfate, uracil, uridine, UMP, dUMP, thymine, thymidine, TMP, TTP, cytosine, cytidine, deoxycytidine; 5-methyl deoxycytidine, CMP, CDP, CTP, dCMP, dCDP, dCTP, cytidine-2', 3 -cyclic phosphate, and 6 -thioguanine $;^{4}$ aminopterin ${ }^{5}$

\footnotetext{
2 New England Nuclear Corp., Boston, Mass.

${ }^{3}$ Worthington Biochemical Corp., Freehold, N. J.

4 Sigma Chemical Co., St. Louis, Mo.

${ }^{5}$ California Corporation for Biochemical Research, Los Angeles, Calif.
} 
Dowex 50W-X4 $\left(\mathrm{H}^{+}\right)$and Dowex 1-X10 $\left(\mathrm{Cl}^{-}\right) ;{ }^{6}$ hydroxide of Hyamine 10X, POPOP [1,4-bis-2-(5-phenyloxazolyl)benzene] and PPO (2,5-diphenyloxazole); ${ }^{7}$ 6-mercaptopurine; ${ }^{8}$ FUDR and 3 '-acetyl-FUDR; ${ }^{9} \beta$-cyanoethyl phosphate prepared by the method of Tener (9) and used to phosphorylate $3^{\prime}$-acetyl-FUDR in the synthesis of FUDRP according to the procedure of Remy and Heidelberger (10); tetrahydrofolic acid and 5-methyl tetrahydrofolic acid prepared by Mr. P. P. K. Ho and Mr. J. Mangum, respectively, using previously described procedures $(11,12)$; and 5-fluorouracil, 5-diazouracil, 6-mercaptopurine ribonucleoside, and 5-iododeoxyuridine. ${ }^{10}$

Criteria for the selection of clinical material used in this study have been give in a previous paper of this series (13). Detailed hematological data on the present patients including course of therapy are presented in a later table.

Leukocytes were isolated by a method described previously (13), suspended in $3 \mathrm{vol}$ of cold $0.05 \mathrm{M}$ barbital buffer, $\mathrm{pH}$ 7.6, and homogenized in a Virtis " 45 " homogenizer at $45,000 \mathrm{rpm}$ for 3 minutes. After centrifugation of the homogenate for 15 minutes at $10,900 \times g$, the sediment was discarded, and the supernatant fraction was used for the enzyme assays. Protein was determined by the biuret method with bovine serum albumin as the standard. Deoxycytidylate deaminase was determined by the method of Maley and Maley (14).

Assay for thymidylate synthetase. The assay used in this study, based upon the incorporation of $\mathrm{HC}^{14} \mathrm{HO}$ into thymidylate, is adapted from several procedures described previously (15-18). The reaction mixture contained in a total volume of $0.8 \mathrm{ml}: 0.7 \mu$ mole of tetrahydrofolate, $1 \mu$ mole $(10 \mu \mathrm{c})$ of $\mathrm{C}^{14}$-formaldehyde, $10 \mu$ moles of $\mathrm{MgCl}_{2}$, $1 \mu$ mole of EDTA, $0.5 \mu$ mole of dUMP, 5 to $15 \mathrm{mg}$ of leukocyte protein, and $50 \mu$ moles of Tris buffer, $\mathrm{pH} 7.5$. The control mixture was identical except for the omission of dUMP. After incubation for 1 hour at $37^{\circ} \mathrm{C}$, the mixture was chilled, and $1 \mu$ mole of carrier TMP was added, followed immediately by the addition of an equal volume of cold $10 \%$ trichloroacetic acid. Protein was removed by centrifugation, and the supernatant fluid was evaporated to dryness. The residue was dissolved in 0.5 $\mathrm{ml}$ of concentrated perchloric acid and heated for 1 hour at $100^{\circ} \mathrm{C}$. The acid was neutralized with $\mathrm{KOH}$, and insoluble potassium perchlorate was removed by centrifugation. The supernatant fraction was passed through a column $1 \mathrm{~cm}$ in diameter containing $3 \mathrm{~cm}$ of Dowex-1-formate over $3 \mathrm{~cm}$ of Dowex-50 $\left(\mathrm{H}^{+}\right)$. The unadsorbed material and the effluent obtained by washing the column with water were pooled, concentrated by heating, and chromatographed on Whatman 1 paper using 1-butanol: water $(86: 14)$ as the solvent system. The

${ }^{6}$ Microchemical Specialties Co., Berkeley, Calif.

7 Packard Instrument Co., La Grange, Ill.

8 Burroughs Wellcome \& Co., Tuckahoe, N. Y.

9 Kindly supplied by Dr. C. Heidelberger and Dr. D. Remy.

10 Gifts of Dr. D. M. Donohue. procedure resulted in the separation of uracil $\left(R_{t}=0.31\right)$ and thymine $\left(R_{\mathrm{f}}=0.52\right)$. The concentration of thymine, after elution from the paper, was determined spectrophotometrically at $264 \mathrm{~m} \mu$ with a millimolar extinction coefficient of 7.9 . A $0.1-\mathrm{ml}$ sample of the thymine-containing solution was dissolved in $2 \mathrm{ml}$ of hydroxide of Hyamine, to which was added $10 \mathrm{ml}$ of toluene, containing $0.01 \%$ POPOP and $0.4 \% \mathrm{PPO}$; the radioactivity in the sample was determined at $950 \mathrm{v}$ in a Packard liquid scintillation counter. All results were corrected for blanks (initial reaction mixture less dUMP) carried through the same procedure; the blank corrections were never larger than $10 \%$ of the experimental values.

The spectrophotometric assay of Wahba and Friedkin (7), which is based upon the absorbancy change at 339 $\mathrm{m} \mu$ associated with the conversion of $N^{5}, N^{10}$-methylene tetrahydrofolate to dihydrofolate, was used for the assay of the partially purified thymidylate synthetase.

Purification of thymidylate synthetase. Two hundred and fifty $\mathrm{ml}$ of blood was obtained from a patient with chronic myelocytic leukemia who had a leukocyte count of 178,000 . All subsequent operations were carried out at $4^{\circ} \mathrm{C}$. The isolated leukocytes (about $35 \mathrm{ml}$ of packed cells) were homogenized in $100 \mathrm{ml}$ of $0.05 \mathrm{M}$ barbital buffer, $\mathrm{pH}$ 7.6, and the homogenate was centrifuged at $10,900 \times g$. One-third volume of $2 \%$ protamine sulfate was added to the supernatant fluid, and the precipitate was removed by centrifugation. The supernatant fluid was then brought to $40 \%$ saturation with solid ammonium sulfate $(24.3 \mathrm{~g}$ per $100 \mathrm{ml}$ of solution), and the resulting precipitate was discarded. The concentration of ammonium sulfate in the supernatant fraction was increased to $60 \%$ saturation by the addition of $13.2 \mathrm{~g}$ per $100 \mathrm{ml}$ of solution. The 40 to $60 \%$ precipitate was collected by centrifugation, dissolved in $10 \mathrm{ml}$ of $0.05 \mathrm{M}$ barbital buffer, $\mathrm{pH}$ 7.6, and dialyzed for 2 hours against the same buffer. The above procedure resulted in a tenfold purification and a $40 \%$ recovery of the enzyme relative to the original homogenate.

\section{RESULTS}

Properties of thymidylate synthetase. With the $\mathrm{HC}^{14} \mathrm{HO}$ assay system, it was established that the rate of the reaction catalyzed by the leukocyte thymidylate synthetase was proportional to enzyme concentration and to time. The $\mathrm{pH}$-activity curve showed a rather broad optimum with the maximum centered around $\mathrm{pH} 6.5$ (Figure 1). In the leukocyte homogenate, the enzyme was stable at $4^{\circ} \mathrm{C}$ for 24 hours, and $50 \%$ of the activity was retained when a dialyzed 40 to $60 \%$ ammonium sulfate fraction was stored at $-20^{\circ} \mathrm{C}$ for 2 weeks.

A component study for Reaction 1 is presented in Table I. There is an absolute requirement for both substrates, dUMP and $N^{5}, N^{10}$-methylene 


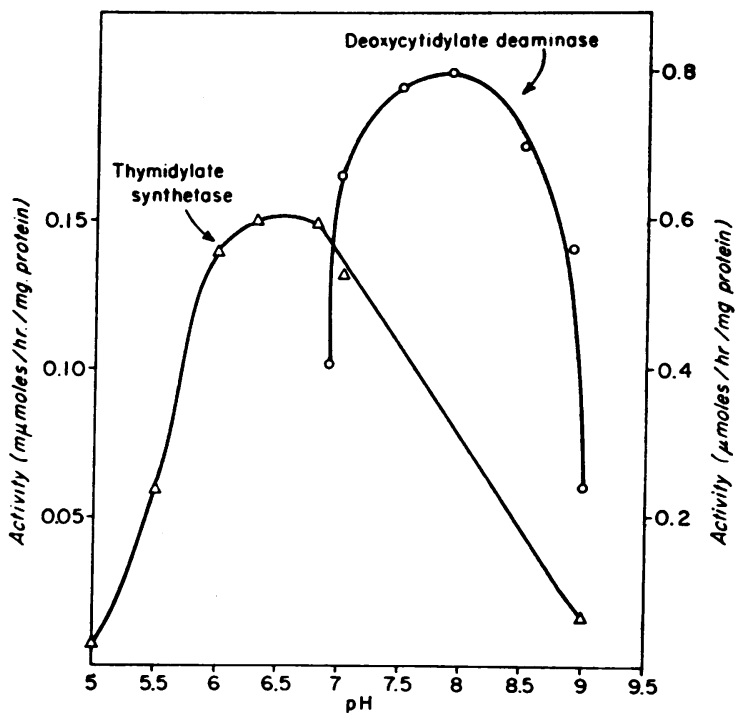

Fig. 1. PH ACTIVITy CURVE FOR THYMIDYLATE SYNTHETASE $(\triangle$, LEFT ORDINATE) AND DEOXYCYTIDYLATE DEAMINASE ( $O$, RIGHT ORDINATE).

tetrahydrofolate (the latter being generated from $\mathrm{HCHO}$ and tetrahydrofolate), and a partial requirement for $\mathrm{Mg}^{++}$and for EDTA. No explanation can be offered at present for the function of the latter component. Substitution of 5-methyl tetrahydrofolate for $N^{5}, N^{10}$-methylene tetrahydrofolate, or of formate for formaldehyde, resulted in a complete loss of activity. The synthetase was also specific for $\mathrm{dUMP}$, since UMP, deoxyuridine, or uracil could not replace the deoxyribonucleotide as the acceptor for the $C_{1}$ group. It should be noted that dCMP can serve as a substrate for thymidylate synthetase in crude preparations, since it is converted to dUMP via deoxycytidylate deaminase; this reaction will be discussed subsequently.

When $1 \mu$ mole of TMP was added to the incu-

TABLE I

Component study for thymidylate synthetase

\begin{tabular}{lc}
\hline \hline Component omitted & Thymidylate synthesized \\
\hline & m mmoles \\
None & 1.9 \\
Tetrahydrofolate & 0 \\
HCHO & 0.02 \\
dUMP & 0 \\
Mg $^{++}$ & 1.0 \\
EDTA & 0.8
\end{tabular}

* Deoxyuridine-5'-phosphate. bation mixture at the beginning of the reaction, rather than added later as a carrier, there was no synthesis of additional thymidylate, demonstrating that the enzyme is inhibited by its reaction product. In the presence of $1 \mu$ mole of thymine or thymidine, thymidylate synthetase was inhibited approximately $50 \%$, whereas the addition of 0.5 $\mu$ mole of TTP or $1 \mathrm{mg}$ of DNA did not affect the rate of thymidylate formation.

When tested at $10^{-4} \mathrm{M}$, the following antimetabolites had no effect on thymidylate synthetase: aminopterin, 5-fluorouracil, 5-diazouracil, 5-iododeoxyuridine, 6-mercaptopurine, 6-thioguanine, and 6-mercaptopurine ribonucleoside. On the other hand, fluorinated pyrimidines markedly inhibited the leukocyte enzyme, confirming previous findings with thymidylate-synthesizing systems from other tissues (18). In Table II, FUDR and FUDRP are compared with respect to their ability to inhibit the leukocyte synthetase. The deoxyribonucleoside is not inhibitory even at $10^{-3}$ $M$, whereas the deoxyribonucleotide still inhibits the enzyme completely at $10^{-6} \mathrm{M}$ and to $40 \%$ at $10^{-7} \mathrm{M}$. The presence of a deoxyribonucleoside kinase, capable of utilizing FUDR as a substrate, is also evident from the data in Table II. Thus, addition of $10^{-2} \mathrm{M}$ ATP to the otherwise noninhibitory FUDR at $10^{-4} \mathrm{M}$ resulted in complete inhibition of enzyme activity. ATP at this level had no effect on the synthetase activity.

The interrelationship of thymidylate synthetase and dihydrofolic reductase has been outlined in Equation 2. The coupling of synthetase and re-

TABLE II

Effect of FUDR and FUDRP on thymidylate synthetase

\begin{tabular}{lcc}
\hline \hline Inhibitor* & Concentration & Inhibition \\
\hline \multirow{3}{*}{ FUDR } & $M$ & $\%$ \\
& $10^{-3}$ & 0 \\
& $10^{-4}$ & 0 \\
FUDR & $10^{-5}$ & 0 \\
+ & $10^{-4}$ & \\
ATP & $10^{-2}$ & 100 \\
FUDRP & $10^{-4}$ & 100 \\
& $10^{-5}$ & 100 \\
& $10^{-6}$ & 100 \\
& $10^{-7}$ & 40 \\
& $10^{-8}$ & 0 \\
\hline
\end{tabular}

* FUDR = fluorodeoxyuridine $;$ FUDRP = fluorodeoxyuridine-5'-phosphate. 


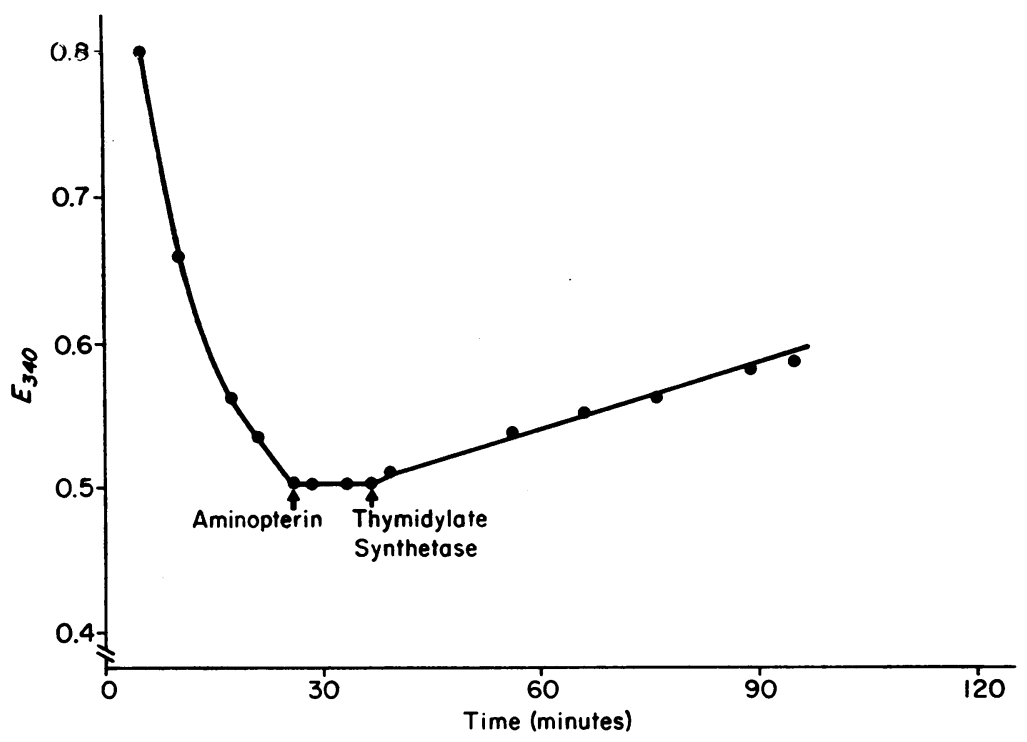

Fig. 2. SPECTROPHOTOMETRIC DEMONSTRATION OF THE INTERRELATIONSHiP OF DIHYDROFOLIC REDUCTASE AND THYMIDYLATE SYNTHETASE. The initial reaction mixture contained the following components in a cuvette of $1-\mathrm{cm}$

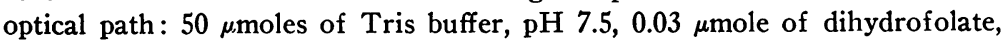
$0.08 \mu$ mole of TPNH, $1 \mu$ mole of $\mathrm{HCHO}, 10 \mu$ moles of $\mathrm{Mg}^{++}, 1 \mu$ mole of EDTA, and $0.2 \mu$ mole of dUMP (deoxyuridine-5'-phosphate) in a volume of $1 \mathrm{ml}$. The optical blank was identical except for the omission of TPNH. The reaction was initiated by adding $2 \mathrm{mg}$ of purified leukocyte dihydrofolic reductase (free from thymidylate synthetase) to each cuvette and measuring the absorbancy change at $340 \mathrm{~m} \mu$. At 25 minutes, $0.01 \mu$ mole of aminopterin was added, and at 35 minutes, $10 \mathrm{mg}$ of purified leukocyte thymidylate synthetase was added. Absorbancy changes were also corrected for separate blanks in which dihydrofolate and dUMP, respectively, had been omitted.

ductase in the leukocyte could be demonstrated by the spectrophotometric experiment shown in Figure 2. The initial reaction mixture contained: purified leukocyte dihydrofolic reductase (containing no synthetase), dihydrofolate, $\mathrm{TPNH}$, $\mathrm{HCHO}$, and dUMP. An identical mixture, omitting TPNH, served as the optical blank. The initial decrease in absorbancy at $340 \mathrm{~m} \mu$ was due both to the conversion of dihydrofolate to tetrahydrofolate and TPNH to TPN. Tetrahydrofolate then reacted chemically with excess $\mathrm{HCHO}$ to form $N^{5}, N^{10}$-methylene tetrahydrofolate, but this step is not accompanied by any appreciable change in absorbancy at $340 \mathrm{~m} \mu$. Aminopterin at $10^{-5} \mathrm{M}$ was added (first arrow) to completely inhibit the reductase, and thus break the cycle. Upon adding purified thymidylate synthetase (second arrow), the increase in absorbancy indicated the regeneration of dihydrofolate from $N^{5}, N^{10_{-}}$ methylene tetrahydrofolate.
Properties of deoxycytidylate deaminase. In leukocyte lysates, the deamination of deoxycytidylate via Reaction 3 was found to be linear with time and enzyme concentration until about $60 \%$

TABLE III

Deamination of cytosine derivatives

\begin{tabular}{lc}
\hline \hline \multicolumn{1}{c}{ Substrate* } & Activity \\
\hline & umoles $/$ hr $/$ mg protein \\
Cytosine & 0 \\
Cytidine & 0.8 \\
Cytidine-2', 3'-cyclic phosphate & 0 \\
CMP & 0 \\
CDP & 0 \\
CTP & 0 \\
Deoxycytidine & 1.1 \\
5-Methyl deoxycytidine & 0.4 \\
dCMP & 0.6 \\
dCDP & 0 \\
dCTP & 0
\end{tabular}

* CMP, CDP, and CTP = cytidine mono-, di-, and triphosphate; dCMP, dCDP, and dCTP = deoxycytidine mono-, di-, and triphosphate. 
of the substrate had disappeared. The $\mathrm{pH}$ optimum for this enzyme was 8.0 , as shown also in Figure 1. When dCMP was deaminated, the product was identified as dUMP by paper chromatography and by its ability to serve as a substrate in the thymidylate synthetase reaction.

The specificity of the deaminase system for various cytosine derivatives is summarized in Table III. In addition to the deoxyribonucleotide ( $\mathrm{dCMP})$, deamination occurred with the deoxyribonucleoside (deoxycytidine), the 5-methyl deoxyribonucleoside, and the ribonucleoside (cytidine). Neither the free base (cytosine) nor the various ribonucleotides [CMP, CDP, CTP, and $2^{\prime}, 3^{\prime}$-(cyc)-CMP] were deaminated.

The mean level of deoxycytidylate deaminase in the leukocytes of ten normal subjects and eight patients with leukemia (acute, chronic myelocytic, and chronic lymphocytic) was $0.5 \mu$ mole per hour per $\mathrm{mg}$ of protein (range, 0.3 to 1.1 ). There was no statistically significant difference in the level of this enzyme between normal and leukemic cells.

Levels of thymidylate synthetase in normal and leukemic leukocytes. The levels of thymidylate synthetase were measured in the leukocytes of 11 normal subjects and 27 patients with leukemia. The results, accompanied by pertinent clinical data for each patient, are tabulated in Table IV. The enzyme was found in the cells of chronic myelocytic leukemia and acute leukemia, but it could not be detected in chronic lymphocytic leukemia or in normal cells. In chronic myelocytic leukemia, thymidylate synthetase was found in all 12 patients who were in relapse; the mean level was $0.19 \pm 0.02 \mathrm{~m} \mu$ mole per hour per $\mathrm{mg}$ protein ${ }^{11}$

11 The extremely low level of thymidylate synthetase in the leukocyte becomes evident when this value is compared in the same units with the formate-activating enzyme ( $960 \mathrm{~m} \mu$ moles per hour per $\mathrm{mg}$ protein) or lactic dehydrogenase $(145,000 \mathrm{~m} \mu$ moles per hour per $\mathrm{mg}$ protein).

TABLE IV

Levels of thymidylate synthetase in leukemia patients

\begin{tabular}{|c|c|c|c|c|c|}
\hline Patient & Diagnosis* & Therapy & Leukocyte count & $\begin{array}{c}\text { Percentage of } \\
\text { mitotic cells } \\
\text { (myelocytes. } \\
\text { promyelocytes, } \\
\text { blasts) }\end{array}$ & $\begin{array}{l}\text { Thymidylate } \\
\text { synthetase }\end{array}$ \\
\hline & & & $/ m l$ & $\%$ & $\underset{\text { protein }}{m \mu m o l e s} / \mathrm{hr} / \mathrm{mg}$ \\
\hline 1 & CML & None & 70,000 & & 0.25 \\
\hline 2 & CML & Busulfan & 73,000 & & 0.13 \\
\hline 3 & CML & $\mathrm{X}$ ray & 111,000 & 30 & 0.18 \\
\hline 4 & CML & Busulfan & 120,000 & 42 & 0.15 \\
\hline 5 & CML & None & 35,000 & 35 & 0.34 \\
\hline 6 & $\mathrm{CML}$ & None & 250,000 & 18 & 0.29 \\
\hline 7 & $\mathrm{CML}$ & None & 45,000 & 9 & 0.10 \\
\hline 8 & $\mathrm{CML}$ & Busulfan & 68,000 & 16 & 0.13 \\
\hline 9 & CML & None & 40,000 & 19 & 0.21 \\
\hline 10 & CML & Colcemid & 14,000 & 63 & 0.23 \\
\hline 11 & CML & Busulfan & 175,000 & 51 & 0.15 \\
\hline 12 & CML & None & 70,000 & 22 & c. 0.06 \\
\hline 13 & ALL & 6-Mercaptopurine & 86,000 & 100 & 0 \\
\hline 14 & $\mathrm{AML}$ & None & 82,000 & 97 & 0 \\
\hline 15 & ALL & None & 17,000 & 39 & 0 \\
\hline 16 & $\mathrm{AML}$ & 6-Mercaptopurine plus prednisone & 52,000 & 93 & 0.07 \\
\hline 17 & $\mathrm{AML}$ & None & 27,000 & 18 & 0.01 \\
\hline 18 & $\mathrm{AML}$ & 6-Mercaptopurine & 150,000 & 96 & 0.06 \\
\hline 19 & ALL & 6-Mercaptopurine plus prednisone & 103,000 & 99 & 0.15 \\
\hline 20 & CLL & None & 44,000 & & 0 \\
\hline 21 & CLI & Chlorambucil & 62,000 & & 0 \\
\hline 22 & CLLL & None & 200,000 & & 0 \\
\hline 23 & CLL & None & 35,000 & & 0 \\
\hline 24 & CLL & Chlorambucil & 40,000 & & 0 \\
\hline 25 & CLL & Chlorambucil & 28,000 & & 0 \\
\hline 26 & CLL & None & 90,000 & & 0 \\
\hline 27 & CLL & None & 43,000 & & 0 \\
\hline
\end{tabular}

${ }^{*} \mathrm{CML}=$ chronic myelocytic leukemia $; \mathrm{ALL}=$ acute lymphocytic leukemia $; \mathrm{AML}=$ acute myelocytic leukemia ; CI.I, = chronic lymphocytic leukemia. 
with a range of 0.06 to 0.34 . Levels of thymidylate synthetase comparable to those occurring in chronic myelocytic leukemia cells have also been observed in two patients with monocytic leukemia. Of considerable interest is the additional finding that two patients with chronic myelocytic leukemia, who were in an acute crisis, showed greatly elevated synthetase levels, i.e., 0.56 and 1.1 m $\mu$ moles per hour per mg protein, respectively.

In two additional patients (not listed in Table IV), thymidylate synthetase activity was determined before and during therapy. The pretreatment levels of the enzyme were 0.12 and 0.11 $m \mu$ mole per hour per mg protein, respectively, and the leukocyte counts were 163,000 and 45,000 . Upon treatment with busulfan and demecolcin, the leukocyte counts decreased to less than 20,000, and there was a proportional decrease in the percentage of immature cells. Concomitantly, the synthetase level decreased and ultimately could not be detected (value $<0.02 \mathrm{~m} \mu$ mole per hour per $m g$ protein). On the other hand, periodic assays performed on untreated patients, or patients not responding to treatment, indicated that the enzyme level did not fluctuate by more than $\pm 30 \%$.

Although we had reported in a preliminary communication (2) that thymidylate synthetase could not be found in acute leukemic leukocytes, the present studies using $\mathrm{C}^{\mathbf{1 4}}$-formaldehyde of a higher specific activity have shown that a low level of thymidylate synthetase $(0.07 \mathrm{~m} \mu$ mole per hour per mg protein) could be detected in four out of the seven acute leukemic patients recorded in Table IV. There was no apparent correlation between patients with the detectable enzyme levels with the type of acute leukemia, percentage of blasts, or therapy.

Thymidylate synthetase could not be cletected in the cells of 12 normal subjects or of eight patients with chronic lymphocytic leukemia. Furthermore, no synthetase activity could be detected in purified fractions from these cells that might be expected to contain the enzyme. For example, the leukocytes from $8 \mathrm{U}$ of normal blood were pooled and fractionated according to the procedure used for the purification of thymidylate synthetase. Both the crude lysate and the 40 to $60 \%$ ammonium sulfate fraction were devoid of any measurable amount of synthetase.
Thymidylate synthetase was also found in two nonleukemic patients with marked leukocytosis. One patient had a leukemoid reaction secondary to carcinoma, and the second had infectious mononucleosis with a leukocyte count of 27,000. The levels of thymidylate synthetase were 0.06 and $0.15 \mathrm{~m} \mu$ mole per hour per $\mathrm{mg}$ protein, respectively; these activities fall within the range of chronic myelocytic leukemia cells.

\section{DISCUSSION}

Winzler, Williams, and Best (19), working with intact leukocytes, have reported that the synthesis of thymidylate, as measured by the incorporation of $\mathrm{C}^{14}$-formate or $\mathrm{C}^{\mathbf{1 4}}$-formaldehyde into DNA, is inhibited by folic acid antagonists. Since this inhibition does not occur with the partially purified synthetase, which catalyzes Reaction 1 , it is evident that the antagonists are inhibiting dihydrofolic reductase, whose relationship to the "thymidylate synthesis cycle" is outlined in Equation 2. Thymidylate synthetase from the leukocyte, which catalyzes the transfer of a $\mathrm{C}_{1}$ unit from $N^{5}, N^{10}$-methylene tetrahydrofolate to deoxyuridylate to yield thymidylate and dihydrofolate, requires $\mathrm{Mg}^{++}$for maximal activity, has a $\mathrm{pH}$ optimum at 6.7 , and is strongly inhibited by FUDRP.

Inhibition of thymidylate synthetase has been demonstrated with FUDRP, the deoxyribonucleotide of fluorouracil; the deoxyribonucleoside, FUDR, is ineffective. The latter compound, however, may merit attention in the treatment of chronic myelocytic leukemia, since it is more readily available than FUDRP and, being nonphosphorylated, passes through cell membranes easily and can be phosphorylated within the cell to yield FUDRP. The enzymatic phosphorylation of FUDR, and an alternate pathway for the synthesis of FUDRP from fluorouracil, have been studied in ascites tumor cells by Reichard (20).

The extremely low level of thymidylate synthetase in the leukocyte presents some difficulties in its detection, but this has been minimized by the use of a $\mathrm{C}^{14}$-labeled substrate having a high specific activity. The fact that thymidylate synthetase activity occurs at a level two to three times lower than that of other relevant enzymes which have been studied, e.g., dihydroorotic dehydrogenase (21) and dihydrofolic reductase (13), supports 
the suggestion (22) that the reaction catalyzed by this enzyme is probably the rate-limiting step in the biosynthesis of DNA. It has been found previously that when thymine-2- $\mathrm{C}^{14}$ was added to suspensions of leukemic leukocytes, $91 \%$ of the labeled material was recovered in DNA, and none was found in the acid-soluble nucleotide pool (23). The administration of other labeled purine and pyrimidine precursors, however, resulted in the labeling of acid-soluble nucleotides. This would suggest that in the leukocyte the pool of free thymidylate is very small and that newly synthesized TMP is converted rapidly to the triphosphate and thence incorporated into DNA via the DNA-polymerase reaction; this suggestion has been substantiated recently by the findings of Bianchi (3).

Information about cellular proliferative activity obtained by cytological and cytochemical techniques in the intact leukocyte, as well as thymidylate synthetase and dihydrofolic reductase levels, is summarized in Table V. Good agreement exists among the various criteria applied to cellular proliferative activity. Chronic myelocytic leukemic cells have the highest rate of thymidylate synthesis (23-25) as judged from the incorporation of labeled precursors (formate, formaldehyde, or thymidine). Similarly, we have found the highest levels of thymidylate synthetase activity in these cells. The mitotic index of chronic myelocytic leukemia bone marrow is also higher than in acute leukemia, chronic lymphocytic leukemia, or in normal cells (26-28).

Acute leukemia appears to be heterogeneous inasmuch as the leukocytes of some, but not all, of the patients $a$ ) incorporate $\mathrm{C}^{14}$-formaldehyde $(24,27)$ and $\mathrm{H}^{3}$-thymidine into DNA and $\left.b\right)$ contain thymidylate synthetase. Chronic lymphocytic leukemic leukocytes and leukocytes from normal subjects do not incorporate $\mathrm{C}^{\mathbf{1 4}}$-formaldehyde into DNA, and only a small percentage of the cells incorporate $\mathrm{H}^{3}$-thymidine into DNA. Thymidylate synthetase is not detectable under the conditions of the present assay in either of the latter cell types. In addition to being metabolically interrelated, dihydrofolic reductase and thymidylate synthetase overlap in their cytologic distribution.

The finding that the level of deoxycytidylate deaminase is the same in both normal and leukemic leukocytes suggests that leukemic cells are not characterized by a uniform increase in all of the various enzymes involved in nucleic acid metabolism. Because of the recent use of halogenated derivatives of cytosine in the chemotherapy of tumors (29), the presence of this deaminase in the leukocyte offers a pathway for the conversion of these agents into the corresponding halogenated uracil derivatives, which may act as inhibitors of enzyme systems or be incorporated into DNA.

Although thymidylate synthetase has been detected in chronic myelocytic leukemic cells and in some acute leukemic cells, but not in chronic lymphocytic leukemic cells or in normal leukocytes, this enzyme is not unique to leukemia, since similar changes are found in infectious mononucleosis. It is likely that the presence of the enzyme is a reflection of the fact that in certain types of leukemia, as well as in infectious mononucleosis, the immature cells are characterized by an increased capacity for DNA synthesis.

\section{SUM MARY}

Thymidylate synthetase, which catalyzes the reaction, deoxyuridylate $+N^{5}, N^{10}$-methylene tetrahydrofolate $\rightarrow$ thymidylate + dihydrofolate, has been partially purified from leukocytes. The en-

TABLE V

Criteria of proliferative activity in leukocytes

\begin{tabular}{|c|c|c|c|c|c|c|}
\hline \multirow[b]{2}{*}{ Cell type } & \multicolumn{2}{|c|}{ Mitotic activity } & \multicolumn{2}{|c|}{ Incorporation into DNA thymidylate } & \multirow[b]{2}{*}{$\begin{array}{l}\text { Thymidylate } \\
\text { synthetase }\end{array}$} & \multirow[b]{2}{*}{$\begin{array}{l}\text { Dihydrofolic } \\
\text { reductase }\end{array}$} \\
\hline & Marrow & Blood & $\begin{array}{l}\mathrm{HC}^{14} \mathrm{OOH} \\
\text { or } \mathrm{HC}^{14} \mathrm{HO}\end{array}$ & $\underset{\text { thymidine }}{\mathbf{H}^{3}}$ & & \\
\hline $\begin{array}{l}\text { Normal } \\
\text { Chronic lymphocytic leukemia } \\
\text { Chronic myelocytic leukemia } \\
\text { Acute leukemia }\end{array}$ & $\begin{array}{c}+ \\
0 \\
+++ \\
++\end{array}$ & $\begin{array}{l}0 \\
0 \\
++ \\
+\end{array}$ & $\begin{array}{c}0 \\
0 \\
+++ \\
+\end{array}$ & $\begin{array}{c}0 \\
+ \\
+++ \\
++\end{array}$ & $\begin{array}{c}0 \\
0 \\
+++ \\
+\end{array}$ & $\begin{array}{c}\frac{1}{+} \\
++++ \\
++++\end{array}$ \\
\hline
\end{tabular}


zymic reaction is assayed by means of the tetrahydrofolate- and deoxyuridylate-dependent incorporation of $\mathrm{HC}^{14} \mathrm{HO}$ into thymidylate. There is also a partial requirement for $\mathrm{Mg}^{++}$in the reaction. Deoxycytidylate can function as a substrate, but only after conversion to deoxyuridylate via a deaminase present in leukocytes. The synthetase has a $\mathrm{pH}$ optimum at 6.5 and is inhibited by 5-fluorodeoxyuridylate and by the reaction product, thymidylate. The continual synthesis of thymidylate involves a cyclic process in which the primary synthetase reaction is coupled with dihydrofolic reductase. The latter enzyme regenerates tetrahydrofolate, which is converted ultimately to the $N^{5}, N^{10}$-methylene clerivative.

The level of thymidylate synthetase has been determined in the leukocytes of 12 normal subjects and 27 patients with leukemia. In chronic myelocytic leukemia, the mean level was 0.19 $\mathrm{m} \mu$ mole per hour per mig protein, and in four out of seven acute leukemia patients, the level was $0.07 \mathrm{~m} \mu$ mole per hour per $\mathrm{mg}$ protein. No activity could be detected in the cells from eight patients with chronic lymphocytic leukemia or from 12 normal subjects.

\section{ACKNOWLEDGMENTS}

The authors are indebted to Mrs. Margaret Albrecht for her assistance on this problem and to Drs. J. R. Czajkowski, D. H. Coleman, Q. B. DeMarsh, D. M. Donohue, and A. Stevens for providing us with blood samples.

\section{REFERENCES}

1. Silber, R., F. M. Huennekens, and B. W. Gabrio. Dihydrofolic reductase and thymidylate synthetase in the leukocyte. Fed. Proc. 1962, 21, 241.

2. Silber, R., B. W. Gabrio, and F. M. Huennekens. Enzymatic synthesis of thymidylate by leukocytes. Clin. Res. 1962, 10, 207.

3. Bianchi, P. A. Thymidine phosphorylation and deoxyribonucleic acid synthesis in human leukaemic cells. Biochim. biophys. Acta (Amst.) 1962, 55, 547.

4. Phear, E. A., and D. M. Greenberg. The methylation of deoxyuridine. J. Amer. chem. Soc. 1957, 79, 3737.

5. McDougall, B. M., and R. L. Blakely. The biosynthesis of thymidylic acid. I. Preliminary studies with extracts of Streptococcus faccalis R. J. biol. Chem. 1961, 236, 832.

6. Blakley, R. L., and B. M. McDougall. The biosynthesis of thymidylic acid. III. Purification of thymidylate synthetase and its spectrophotometric assay. J. biol. Chem. 1962, 237, 812.

7. Wahba, A. J., and M. Friedkin. Direct spectrophotometric evidence for the oxidation of tetrahydrofolate during the enzymatic synthesis of thymidylate. J. biol. Chem. 1961, 236, PC11.

8. Wahba, A. J., and M. Friedkin. The enzymatic synthesis of thymidylate. I. Early steps in the purification of thymidylate synthetase of Escherichia coli. J. biol. Chem. 1962, 237, 3794.

9. Tener, G. M. 2-cyanoethyl phosphate and its use in the synthesis of phosphate esters. J. Amer. chem. Soc. 1961, 83, 159.

10. Remy, D., and C. Heidelberger. Personal communication.

11. Hatefi, Y., T. P. Talbert, M. J. Osborn, and F. M. Huennekens. Tetrahydrofolic acid. Biochem. Preparations 1960, 7, 89.

12. Sakami, W., and I. Ukstins. Enzymatic methylation of homocysteine by a synthetic tetrahydrofolate derivative. J. biol. Chem. 1961, 236, PC50.

13. Bertino, J. R., R. Silber, M. Freeman, A. Alenty, M. Albrecht, B. W. Gabrio, and F. M. Huennekens. Studies on normal and leukemic leukocytes. IV. Tetrahydrofolate-dependent enzyme systems and dihydrofolic reductase. J. clin. Invest. 1963, 42, 1899.

14. Maley, G. F., and F. Maley. Nucleotide interconversions in embryonic and neoplastic tissues. I. The conversion of deoxycytidylic acid to deoxyuridylic acid and thymidylic acid. J. biol. Chem. 1959, 234, 2975.

15. Flaks, J. G., and S. S. Cohen. Virus-induced acquisition of metabolic function. I. Enzymatic formation of 5-hydroxymethyldeoxycytidylate. J. biol. Chem. 1959, 234, 1501.

16. Barner, H. D., and S. S. Cohen. Virus-induced acquisition of metabolic function. IV. Thymidylate synthetase in thymine-requiring Escherichia coli infected by $\mathrm{T} 2$ and $\mathrm{T} 5$ bacteriophages. J. biol. Chem. 1959, 234, 2987.

17. Maley, F., and G. F. Maley. Nucleotide interconversions. II. Elevation of deoxycytidylate deaminase and thymidylate synthetase in regenerating rat liver. J. biol. Chem. 1960, 235, 2968.

18. Hartmann, K-U., and C. Heidelberger. Studies or: fluorinated pyrimidines. XIII. Inhibition of thymidylate synthetase. J. biol. Chem. 1961, 236. 3006.

19. Winzler, R. J., A. D. Williams, and W. R. Best. Metabolism of human leukocytes in vitro. I. Effects of A-methopterin on formate- $\mathrm{C}^{\mathbf{1 4}}$ incorporation. Cancer Res. 1957, 17, 108.

20. Reichard, P. Biochemical changes during treatment with 5-fluorouracil. Second Conference on Experimental Clinical Cancer Chemotherapy. Cancer Chemotherapy Report Feb., 1962, p. 347.

21. Smith, L. H., Jr., F. A. Baker, and M. Sullivan. Pyrimidine metabolism in man. II. Studies of leukemic cells. Blood 1960, 15, 360. 
22. O'Brien, J. S. The role of the folate coenzymes in cellular division. A review. Cancer Res. 1962, 22, 267.

23. Wells, W. In vitro incorporation of formate into nucleic acid derivatives of normal and leukemic human leukocytes. Ph.D. thesis, University of Illinois, 1959.

24. Scott, J. L. Human leukocyte metabolism in vitro. I. Incorporation of adenine-8- $\mathrm{C}^{14}$ and formate- $\mathrm{C}^{14}$ into the nucleic acids of leukemic leukocytes. J. clin. Invest. 1962, 41, 67.

25. Craddock, C. G., and G. S. Nakai. Leukemic cell proliferation as determined by in vitro deoxyribonucleic acid synthesis. J. clin. Invest. 1962, 41, 360.
26. Dameshek, W., and F. Gunz. Leukemia. New York, Grune \& Stratton, 1958, p. 87.

27. Astaldi, G. Differentiation, proliferation and maturation of haemopoietic cells studied in tissue culture in Ciba Foundation Symposium on Haemopoiesis, G. E. W. Wolstenholme and M. O'Conner, Eds. Boston, Little, Brown, 1960, p. 99.

28. Gavosto, F., G. Maraini, and A. Pileri. Proliferative capacity of acute leukaemia cells. Nature (Lond.) $1960,187,611$.

29. Cramer, J. W., W. H. Prusoff, A. C. Sartorell, I. W. Delamore, P. K. Chang, C. F. von Essen, and A. D. Welch. Effects of 5-iodo-2'-deoxycytidine (ICDR) in vitro, in culture, and in vivo. Proc. Amer. Ass. Cancer Res. 1962, 3, 312. 